\title{
The Universal Meanings of Common Discourse
}

Intrasubjective and Intersubjective Communication in George H. Mead

Anna M. Nieddu

\section{CpenEdition}

1 Journals

Electronic version

URL: http://journals.openedition.org/ejpap/351

DOI: 10.4000/ejpap.351

ISSN: 2036-4091

Publisher

Associazione Pragma

\section{Electronic reference}

Anna M. Nieddu, «The Universal Meanings of Common Discourse », European Journal of Pragmatism and American Philosophy [Online], VII-1 | 2015, Online since 07 July 2015, connection on 19 April 2019 URL : http://journals.openedition.org/ejpap/351 ; DOI : 10.4000/ejpap.351

This text was automatically generated on 19 April 2019

\section{(c) $($ ) $\odot$ (8)}

Author retains copyright and grants the European Journal of Pragmatism and American Philosophy right of first publication with the work simultaneously licensed under a Creative Commons AttributionNonCommercial-NoDerivatives 4.0 International License. 


\title{
The Universal Meanings of Common Discourse
}

\author{
Intrasubjective and Intersubjective Communication in George H. Mead
}

Anna M. Nieddu

\section{Introduction}

1 A critical and aware return to pragmatism entails preliminary focus upon the possibilities of productive communication and a possible exchange among fields of research often far apart in terms of methods and spheres of application. This difficulty is even more significant if we refer to the intellectual legacy of George H. Mead, often divided between opposing and conflicting fields of investigation.

2 This paper focuses upon Mead's anthropological vision, seen in the light of an ethical approach. On this basis, some new connotations of human complexity - expressed by Mead or resulting from his works - may still emerge, enriching discussion of the 'outside/ inside' relationship that works in communicative processes and pointing out its role in a new emerging notion of rationality. The belief that guides my re-examination of Mead's dynamics of the Self is relative to the strength and effectiveness of the work of renewal performed by the pragmatist in a distinctive philosophical-anthropological field. It is a renewal that involves some hypotheses of research whose value and effectiveness could be suitably tested both in the sociological and political fields, effectively building a bridge between the two sides.

3 My analysis develops from some general guidelines that have emerged in the intense debate concerning "creativity" and "authenticity" that took place, notably in Germany, during the 1990s. ${ }^{1}$ In dealing with problems connected with the theory of the self, Mead scholars increasingly emphasized the role of the " $I$ " within personality dynamics, both as regards the function it exercises in constructing a personal identity and as regards its specific contribution to social reconstruction. In formulating a theoretical position inspired by his studies on Pragmatism, in Die Kreativität des Handelns Hans Joas outlines a concept of creative action as: "a third model of action" to add to the two predominant 
types: the rational action and the normatively oriented action. The model of action proposed stresses the creative nature of human action, and points out that a creative dimension exists in all human action, a dimension inadequately expressed in the neo-Weberian and neo-Parsonian models (Joas 1996). A similar commitment - partially addressed to a reexamination of Habermas - is present in some works by Honneth, collected in a volume in 1995. In this essay collection, Honneth reformulates his concept of personal autonomy in terms of a decentred autonomy, that is, also taking into account the "unconscious spontaneity of the I," considered a key concept in understanding processes of the Self in their entirety and complexity. Therefore, Honneth's concept of decentralized autonomy represents his response to the decentralization of the subject, set in motion by Nietzsche's criticism of the classical concept of autonomy and supported by Freud's psychoanalytic theory through the discovery of unconscious involuntary impulses that compel human action. By connecting Mead's social psychology and Winnicott's psychoanalysis, Honneth proposes an extended psychoanalytical conception of inter-subjectivity, according to which the unconscious and the uncontrollable forces of the linguistic meaning event show themselves as constructive conditions for the acquisition of personal autonomy. In this way, according to Honneth, a comparison with the conception of the subject emerging from psychoanalysis confirms and extends his theory of recognition (Honneth 1995, 2002).

Joas and Honneth seem to agree that the renewal of philosophical attention to the process of individualization may permit a more open and direct comparison even with positions inspired by an ethics of authenticity, more or less directly linked to Charles Taylor's indications (Taylor 1991).

5 Honneth observes that the philosophical-political debate of the 1970s and 1980s almost always led to unsatisfactory results regarding the 'pathologies' of social integration:

[...] with the exception of the more recent works of Charles Taylor, which in the form of a conceptual clarification of the idea of authenticity, point in the direction of a substantive philosophical diagnosis of the present era. (Honneth 1995: xxii)

6 Joas, on the other hand, stresses the positive role exerted by Taylor - together with Berlin - in contrasting "utilitarian tendencies of Enlightenment" by means of an expressionistic counter-model of action (Joas 1996: 128). Indeed, the two social philosophers maintain that in proposing a 'post-metaphysical' foundation for an ethics of authenticity, it is important to underline how in Mead the inter-subjective dimension of the "Self" is not in contrast with a recognized value of the expressions of "I." In some sense, in fact, intersubjectivity is inherent to that we call the intra-subjective dynamics of "I/Me" dialogue. In agreement with a certain interpretative tendency - more or less connected to the debate I quote above (Ferrara 1998; but also Tugendhat 1979) - these two interpretations converge on the possibility of recovering an anti-substantial notion of authenticity, a convergence that is also informed by Mead. In this way, it becomes possible to give to all questions of authenticity a new direction, radically different from the one toward which various lines of research - more or less vaguely inspired by Heidegger's approach to this problem have seemed to lead.

7 I agree with this requirement and, on this point, I think it is essential to set acting - rather than being - at the centre of philosophical attention. However, I also think that it is possible to perform another, but no less important, step by reflecting upon the path covered by Mead as regards the whole question of creativity, conceived by the pragmatist as the authentic stuff of humanity. Concerning this point, the major problem becomes the 
constitution of a series of new points of reference starting from Mead's suggestions, which I here indicate as the dynamics of human nature and its temporalist, or better, historicist constitution.

8 Can an idea of human nature lose its ontological foundation without losing its effectiveness in supporting universal ethical values such as the dignity of the human person or - on the legal and political side - the universality of human rights? Can a radically individualized notion of the human person, such as the one that we infer from Mead's suggestions better work out this problem? Moreover, can a new notion of authenticity connected to Mead's idea of the value of individuality offer a more believable answer to the need for a renewed civil ethics that distinguishes our time?

We know that, according to Mead, thanks to linguistic mediation, the genesis of the "I" takes place in a radically inter-subjective context, so that it manifests the personal, unique and unrepeatable perspective of every individuality. In its manifestations, the motives for individual action emerge, made up of personal needs, impulses, aspirations and desires. No personal experience appears meaningless inside this frame of reference. The various productions of the 'T's experience' originate and develop according to specific modalities; among them, the role of imagination in experiential processes appears irreplaceable. Rationality is depicted as complex and dynamic, not confined to logical-formal processes of organized thought, but involving and containing within it all the processes of ideas formation, including those connected to the so-called unconscious activity of the Self. A sort of imaginative reason originally produces language itself, instrument and vehicle of social transformation. Within this framework, the notion of perspective assumes a role of great significance. It represents not only the possibility of combining universalism and 'pluriversalism,' as in W. James or A. N. Whitehead, but precisely locates "sociality" as the place of the intersection of meanings and communicative exchanges (Mead 1932).

Given this background, it would be interesting to investigate the effects of those philosophical-anthropological views that emerge from Mead's idea of the creative, temporalist, or historicist, processes through which all selves build their humanity. In this direction, it could be decisive to consider the dynamics of 'intra-subjective and intersubjective communication' that, in Mead's view, constitute the horizons of one's own perspective (i.e. something more complex than a simple inner/outer point of view), that is, the constitutive moments of an ethical self-construction of human beings. On these bases, the peculiarity of human creativity, in all its complexity, reveals itself as the starting point for a responsible normatively oriented conduct. At the same time, the excesses of a unidirectional, and biologically oriented, reading of the human constitution clearly demonstrate their boundaries.

11 I believe that the entire framework of Mead's philosophy that would result could better delineate the same idea of creative action. For some critics, Joas unsatisfactorily define the latter results in his 1992 book Die Kreativität des Handelns (Colapietro 2009). Above all, I see a close relationship between creativity of the self and responsible conduct. In Mead, motives for actions lie in a kind of behaviour in which the moment of conscious responsibility constantly links itself with the expression of what is novel in experience. In this way, moral life sustained by social ends and fed by all the knowledge that science can offer, in a certain sense, demands the creativity of the Self (Mead 1934: 178).

These indications demonstrate how reading Mead's texts in this sense could emphasize those aspects linked to the expression of individual creativity and their relationship with social reconstruction. Concerning this point, it also seems important to stress how, in 
general, processes of "taking-roles" refer to an idea of rationality strengthened and enriched by imagination, that is: a 'poietic' rationality, which is effective and productive in creative acting. In this way, an original anthropological paradigm is attested too; a paradigm that can still be a source of inspiration for a pattern of civil life and democratic citizenship.

\section{Experiencing Creativity: the Function of Imagery}

My first step consists in recalling the role that the imagery covers in an iconic form of outer/inner communication, able to reconnect to the process that I will indicate as a continuous - conscious and unconscious - 'stream of experiences.' Creativity, in fact, has to be experienced.

According to Mead, in experiential dynamics, the images have the double function of memory and prediction. They connect themselves to the memory of experiences but resurface unintentionally in view of possible future reorganizations:

Toward that which is emerging our action takes us and what is disappearing provides the conditions of that action. Imagery then comes in to build out both stretches. We look before and after, and sigh for what is not. (Mead 1934: 345)

The images of old experiences, meaningful in their visual immediacy, belong to the unconscious sphere of the Self and potentially represent the matter on which so-called introspection - thought by Mead as self-communication - applies itself. Unlike what Freud has maintained, the unconscious of which Mead speaks represents a sort of store of resources from which the "I" can freely draw during the fortuitous connections and reconnections of experience. Even if the relationship between Mead and psychoanalysis is recurrent in philosophical debate, Mead's reservations regarding Freud's theory are well known, and I think we must take them for granted:

In the more or less fantastic psychology of the Freudian group thinkers are dealing with the sexual life and with self-assertion in its violent form. The normal situation, however, is one which involves a reaction of the individual in a situation which is socially determined, but to which he brings his own responses as an 'I.' (Mead 1934: 211)

In the passage quoted above, Mead refers to "the normal situation" as a context within which a form of "social control" operates by means of the 'I/Me' dialogue. This is: "[...] the control which the individual is able to exercise over his own responses" (Mead 1934: 254). The function of the " $\mathrm{Me}$ " in experiential processes represents a sort of translation of the language of the social group and it constitutes a threshold that the "I" must exceed. In this sense - but only in this sense - the "Me" represents "a censor" (Mead 1934: 255). In the intrasubjective experience in which it operates, the "Me" represents the receptacle for ever-new acquisitions linked to a change in customs and to the enrichment of the patrimony of shared social values. This change and enrichment derive from the progressive passage into the "Me" of the contents of the " $\mathrm{I}$ " that have been recognized at the level of the social group.

Mead's psychological views do not appear reductive relative to the nature of impulses or substantial as regards the nature of the unconscious. At any time, creativity can be realistically expressed in artistic or scientific productions that seem to temporarily stop and crystallize the stream of experiences, but never the thread of connections between conscious and unconscious junctures forever defining the boundary between separate 
worlds as in Freudian theory. In these connections, imagination operates as a form of 'unforeseeable thought', not illogical nor alogical, but endowed with a peculiar kind of logic that operates by experiencing the interconnections between objects and images, facts and dreams, weighted reflections and unrestrained daydream. So, from this viewpoint it becomes important not only to stress how a Freudian unconscious sphere can become a condition rendering autonomy possible by means of its recognition in intersubjectivity, ${ }^{2}$ but also to pay attention to the particular function exercised by that same sphere in constituting individual conduct with relation to future achievements. The contents of the " $I$ " that are not able to assert themselves at a particular time do not, in fact, lose their potential validity as regards still-unspecified future situations. As we will see with reference to the aesthetic experience, the fluidity of temporality expressed by Mead plays a fundamental role in defining experiential processes. ${ }^{3}$

Thus, it seems relevant to consider the contribution of this kind of apparently free logic to the complex formation of the identity and authenticity of every Self. The process of selfproduction seems to be oriented in a peculiar direction thanks to the specific angle from which every "I" intervenes on a personal store of images of experiences, connecting and mixing them according to unique modalities, to set up a specific perspective. In the selfreflective processes within which combinations of ideas and images express themselves, creative productions emerge because of personal and often fortuitous and unpredictable connections. When this process is intentional, it produces the individual's original responses that can give body to works of art, new world visions or value proposals.

Imaginative activity is thus an integral part of logical processes within which it exercises a predictive function. The apparently aseptic phases of the act of reflecting described by Mead in The Philosophy of the Act are not 'troubled' because of the discovery of the variegated context in which they are found to work, that is, among free play, or occasional encounters, or the variegated combinations of images that continuously succeed each other. In experiential processes, inter-subjective and intra-subjective communications mutually interfere, exchanging their positions in a complex intersection of perspectives. This web of perspectives with its weave of subjectified and objectified threads at last constitutes the entire universe of meanings. ${ }^{4}$ In this way, transfer within the Self of the contents of the so-called interior experience cannot occur automatically, as in $\mathrm{H}$. Bergson, ${ }^{5}$ through a sort of imposition necessitated by the spiritual strength of a deified creative activity. Also, in this sense, the " $\mathrm{I} / \mathrm{Me}$ " communication has a 'democratic' role: that of translating the proposals of the " $\mathrm{I}$ " into a socially shared language, relating without enslaving them - to the habits, norms and values recognized in the social group.

\section{Suggestions from Emerson: Art, Imagination, and the Taking-Role}

Following Mead's indications, therefore, we can outline a dynamic notion of human creativity, set and kept in motion by the activity of the "I," an activity in which imagination has a vital function and promotes the use of a language orienting activity toward ever-new objects. The role of imagery in experience thus returns as a problem in this philosophical research, where a prominent role is given to the value of discovery.

of course, these assumptions do not mean that a 'visionary logic' prevails in the thought processes and that imaginative activity has a greater role than reason. Rather, it means 
that one gives to the other material to work on, using communicative instruments that are functionally but not substantially different among them. Just as for Peirce, also for Mead a logic of discovery needs to recognize and to assign a precise role to abductive and iconic moments, that is, to the predictive and representative moments of every logical process. Mead, however, goes further than Peirce does in the applied part of his epistemological project. His intent consists in demonstrating the practical relapses of the pragmatic assumption relative to the 'real nature' of human rationality; an expressive and creative 'nature' in which logical, ethical and aesthetic experiences work together to recognize the primary normative character of a radically human action. This action is situated because the agent too is a situated being, but it has the capacity to inscribe itself upon its surroundings thanks to its inherent creativity.

Nevertheless, I think it is important not only to recall the influence of the expressivist European tradition on the pragmatist's theory of creative action (Joas 1996) but also the influence of Transcendentalism upon American philosophy between the end of the 19th and the beginning of the 20th centuries (Nieddu 2001). In fact, even Mead and Dewey, whilst persuaded Darwinians not sharing the cosmological background of Transcendentalism, were not averse to some striking Emersonian suggestions. Dewey's link to Emerson's source is more definite than Mead's and, perhaps, the resonance of some 'romantic' echoes in Mead derives from the influence of Dewey. In this paper I do not analyse this problem or, in general, the problem of the relation between the two pragmatists. I prefer to concentrate on the particular way - original in more than one aspect - in which the memory of Transcendentalism operates in Mead's ethical and social thought.

As regards these problems, students' notes on a series of lessons on social psychology held by Mead in 1914 and first published in 1982 by David Miller - are extremely significant. Their subject is the relationship between art, imagination, and role assumption. The latter, in some ways, seems to need the artist's social function. According to Mead, it seems possible to grasp the relationship between literature, philosophy, psychology and social science recognizing the effectiveness of literary tools in the portrayal through imagery of the 'stream of experiences.' They appear more 'realistic' as regards those elaborated by means of the best philosophical, psychological and sociological analysis and interpretations. In literary expressions too, the logical connections between the representations mentioned above and the actions triggered by them are more vivid and efficacious, and sometimes more 'truthful.' Obviously, these suggestions coming from Mead do not mean that literature should take the place of other disciplines. I rather think that he - like Emerson and Whitman - fruitfully underlines the value of a joint collaboration between them. ${ }^{6}$ However, I take for granted too that scientific knowledge is born not out of this working agreement. It seems to me that for the pragmatists of every era fallibilism is the only precondition for every assumption. As in Dewey so in Mead, the giving up the claim that one's truth coincides with absolute truth really represents the unique form of religion consistent with democratic life.

Therefore, I believe that the strength of Mead's suggestions resides in the possibility of enriching the chances of creating ever-new intersections of perspectives by means of every human tool, according to some indications that he elaborated in the final years of his life in The Philosophy of the Present. Nevertheless, before closing I would like to consider for a moment some other of Mead's insights on the relationship between aesthetic and ethic experiences emerging from the lessons of 1914 . What strikes us immediately in these 
lessons is the close relationship he reaffirms between taking role and imagination, a link that allows us to see the direct analogy between social and ethical attitudes and artistic production: "Problems involved in social reforms are thought out through persons putting themselves in others' places" - Mead affirms - and subsequently:

The way a community comes to realize a social evil is by taking the role of another individual who is subject to injustice. The community needs that sort of imagery and meaning. The artist is to a large degree working out that imagery which is most useful in thinking. (Mead 1982: 98)

Art has always helped to strengthen social relationships and the intellectual growth of peoples thanks to the creation of an imagery in which individuals can reflect upon group values and identify with them:

The social function of the artist is to provide imagery for thinking from all points of view. The community cannot bring itself to realize these other relations until it gets imagery from the artist. (Mead 1982: 100)

The artist obtains this result by portraying problems and social evils with the instrument provided by the significant images belonging to narration, as occurs within different literary expressions. In these affirmations, the assumptions of a philosophical conception based upon sharing in the universality of the significant products of inter-subjective relationships become explicit, without underestimating the contribution of the " $I$ ":

[...] The individual in a certain sense is not willing to live under certain conditions which would involve a sort of suicide of the Self in its process of realization. Over and against that situation, we referred to those values which attach particularly to the 'I' rather than to the 'me', those values which are found in the immediate attitude of the artist, the inventor, the scientist in his discovery, in general in the action of the 'I' which cannot be calculated and which involves a reconstruction of the society, and so of the 'me' which belongs to that society. It is that phase of experience which is found in the ' $\mathrm{I}$ ', and the values that attach to it are the values belonging to this type of experience as such. These values are not peculiar to the artist, the inventor and the scientific discoverer, but they belong to the experience of all selves where there is an 'I' that answers to the 'me.' (Mead 1934: 214)

The expressions of the "I" intervening in the formation of the individual Self are also active in its relationship with the social context and make every individual unique in their ability to respond authentically to the stimuli of variegated human situations according to a particular, unique perspective:

The fact that all Selves are constituted by or in terms of the social process and on individual reflections of it - or rather of this organized behavior pattern which it exhibits, and which they pretend in their respective structures - is not in the least incompatible with, or destructive of, the fact that every individual Self has its own peculiar individuality, its own unique pattern [...] The organized structure of every individual Self within the human social process of experience and behavior reflects, and is constituted by, the organized relational pattern of that process as a whole; but each individual Self-structure reflects, and is constituted by, a different aspect or perspective of this relational pattern, because each reflects this relational pattern from its own unique standpoint. (Mead 1934: 201)

On this occasion, it is not possible to analyse in detail the relapses of Mead's concept of perspective in the ethical-political sphere, particularly as regards the theme of justice or the individual's contribution to the establishment of shared values. The innovative aspect of the theory of perspectives in the field of value production lies in the possibility of drawing attention to individual contributions to the formation of shared ideals. The uniqueness of the perspective of every Self permits, in fact, the introduction of new 
elements of discussion or proposals of values within the social group thus promoting social reconstruction and democratic growth, set in motion precisely by individual responses (Mead 1934: 168).

In conclusion, it is worth pointing out how, even in light of the theory of perspectives, the value assigned to the creativity of the "I" in proposing solutions to problems implicit in the manifold forms of the Self's experience is confirmed. According to Mead, the activity of the "I" is more complex than the biological datum of spontaneity. The manifestations of the "I" within the thought processes and the role they play in the social sphere thicken the frame of reference of the human universe. Mead's philosophical anthropology, indeed, seems to focus upon a concept of the psychological diversity of individuals more complex than that of the genetic diversity attested to in biology, however compatible they may be. The fortuitousness of genetic combinations, in fact, changes itself in the fortuitousness of the intersection of different perspectives.

The Self emerges from the increasingly complicated weave of intra-subjective and intersubjective communication that takes place after the individual has developed the capacity to present herself within numerous perspectives. This communication promotes a mobile representation of themselves in which the play of expectations, volitions, desires, reminiscences, recollections, and self-images exerts its distinctive role. It is precisely through this play that the "I," articulating its expressions, offers its irreplaceable contribution to the constructions and reconstructions of civil society.

31 In this way, the uniqueness of individual responses seems to lose the features of exactitude and absoluteness that characterize both the spontaneity of the "I" theorized on a merely biological plane, as in Darwin's theory of evolution, and the one conceived on a merely spiritual plane, as in Bergson's creative evolution (Bergson 1907). In the complex self-constructive development of human personality, uniqueness is rather expressed by the non-repeatable modality in which what Mead defines as Mind - attributing a linguistic-communicative, relational and thus social nature to it - interacts with the "universe of thought" of every Self (Mead 1934: 133). These processes constitute the varied, many-faceted 'interior world', which is not understood as a simple set of clarified previous experiences, but as a sort of seething cauldron of expressive potentialities. The latter are still obscure and indefinite because they have not been engaged at the conscious level or they are merely projected into the future as intentions, resolutions or plans for action. The ability to be responsible in achieving self-fulfilment and selfdetermination without sacrificing one's authenticity, cannot thus deprive itself of the potential value of the multiple and complex expressions deriving from those unique combinations of conscious/unconscious dynamics constituting each personality.

Literature appears to Mead particularly effective in representing the modalities and the disturbing outcomes of this complex and variegated way of experiencing themselves. A way which is antithetical to Descartes' cogito.

\section{Universal Meanings and Chaotic Visions: Joyce versus Descartes}

Aesthetic experience springs from "consummation," a particular attitude to what surrounds us and permits us to grasp its beautiful, gratifying elements. ${ }^{7}$ It is really that substrate, made up of a texture of reason and sentiment, which represents the thread of 
the experiential process. It ensures continuity even in moments of absent-mindedness or when action ceases. This happens every time we succeed in combining images of the past with ideals that we would like to pursue. According to this interpretation, not only language, as a means of inner/outer communication, but also history lose any sort of substantial nature. History, in particular, propose itself as a privileged field of experimentation of the various present/future finalities that we would like to achieve in our "common action," or specific situation. As Mead writes in The Nature of the Aesthetic Experience:

While the aesthetic attitude which accompanies, inspires, and dedicates common action finds its moment of ideal finality in future achievement, the material in which its significance and beauty is fashioned is historic. (Mead 1964: 298)

The expression of these moments also animates literature: "Tolstoy, as an officer in the war gives an account of having pictures of his past experience in the midst of his most intense action" (Mead 1934: 137). In this example, which considers an everyday situation, a contrast with an experience completely oriented towards external activity is present. An experience: "[...] in which the Self as an object does not enter, and an activity of memory and imagination in which the Self is the principal object" (Mead 1934: 137). History appears simultaneously as the archive of old experiences that await their rebuilding and as the place of destination of what we would like to achieve:

All the stuff with which the most creative imagination works is drawn from the storehouses and quarries of the past. All history is the interpretation of the present, that is, it gives us not only the direction and trend of events, the reliable uniformities and laws of affairs, but it offers us the irrevocableness of the pattern of what has occurred, in which to embody the still uncertain and unsubstantial objects we would achieve. [...] All this is healthful and normal. In its perfection, it reaches the field of the fine arts, but it involves the creative imagination and aesthetic appreciation of the least artistically endowed of those who are fortunately engaged in the rewarding undertakings of life. (Mead 1964: 298)

Therefore, in more than one way, "the stuff" which humanity is made of appears temporalist and historicist as well; "continuity" represents the keystone of the human way of relating to time and history, as Mead writes in The Nature of the Past:

The past which we construct from the standpoint of the new problem of today is based upon continuities which we discover in that which has arisen, and its serves us until the rising novelty of tomorrow necessitates a new history which interprets the new future. [...] Within our narrow presents our histories give us the elbowroom to cope with the ever-changing stream of reality. (Mead 1964: 353)

Passages such as this portray perfectly the interpenetration of time and nature, history and human beings. The 'authentic nature' of humanity reveals itself historic, not ethically determined by the settled ethos but intrinsically connected to that "ever-changing stream of reality" that represents the battlefield upon which the normative action of human beings has to engage. History, in turn, is not just an arid collection of facts. It is not simple erudition but philosophy of humanity. For an Italian reader - but not only - in this assumption resounds an echo of G. Vico's La scienza nuova, and I really think that it would be very interesting to analyse thoroughly this connection, as has been done in the case of Peirce. ${ }^{8}$ However, on this occasion I will simply indicate a future line of research and, rather, consider Mead's nearest sources of inspiration.

As we have seen, according to Mead the best representation of what I call stream of experiences is the variety of the artistic experiences. In The Nature of Aesthetic Experience, he examines the ways in which the thought processes also develop through the free play 
of fantasy and imagination. He distinguishes between pure daydreaming - "stream of reverie" (Mead 1964: 300), which has no bearing upon reality, but only produces in certain circumstances useful escapes to relieve subjective distress - and the work of the imagination. This latter shows itself in ideal meanings, generated by the aspirations of the moment. These aspirations, in turn, throw human conduct toward the future in the form of projects. And these processes always begin from the concreteness of human needs; a concreteness that triggers motivations of acting and situational thinking that are capable of influencing conduct normatively through the imaginative representation of rewarding expectations.

In fact, in approaching the objects of experience two distinct dimensions, two forms of approach that relate to two distinct orders of purpose are given. In the first dimension: "[...] we give attention only to that which forwards the undertaking: we see and hear only enough to recognize and use, and pass from the recognition to the operation." By contrast, in appreciation: "[...] we contemplate, and abide, and rest in our presentations" (Mead 1964: 297). Action is no longer continuous, it is not continuity of experiences in itself. According to Mead's suggestions, what I call the stream of experiences is made up of a variegated mixture of thoughts and tastes that accompanies every moment of ordinary life. This complex constitution builds the humanity of human animals:

The artisan who stops to sense the nice perfection of a tool or a machine has interrupted its use to appreciate it and is in an aesthetic mood. He is not interested in its employment, he is enjoying it. The statesman who turns from the construction of his speech, the ordering of his statistics, the meeting of political opposition, the whole technique of putting across his projects for bettering conditions and life of children, to the picture of their healthful and joyous life, is for the time being no longer in action. He is savoring the end that he is fashioning into practicable politics. When one stops in his common labor and effort to feel the surety of his colleagues, the loyalty of his supporters, the response of his public, to enjoy the community of life in family, or profession, or party, or church, or country, to taste in Whitmanesque manner the commonalty of existence, his attitude is aesthetic. (Mead 1964: 297-8)

In Mead's opinion, literary expressions - novels and poetry - together with theatrical or cinematographic production can represent the functioning of the Self better than many psychological or sociological treatises. They can dwell upon the digressions of the " $\mathrm{I}$ " in images that clarify the contents of the full experience of the Self, including irrelevant, scandalous or risky imagery. At some particular communicative levels, depictions in narration or performance of the intense, often disjointed, activity of estrangement of the Self may exercise an extremely important cathartic function:

[...] There should be a certain release, and relief from restraint, which comes from the fulfilment of the escape reaction with a richness of imagery which the inner imagination can never offer. If these escape reactions play any legitimate part in the economy of keeping house with one's Self, and I think they do, the elaboration of them at just the point where the imagination fails should emphasize that function, and the enjoyed imagery is genuinely aesthetic. (Mead 1964: 304)

At other times, literature vividly and sometimes brutally expresses psychological situations consisting of chaotic visions produced by an incessant emergence from desires, disconnected memories and unspeakable experiences, as happens in Joyce's Ulysses. ${ }^{9}$ However, in spite of everything, the expression of the private and disjointed imaginings of the characters in Ulysses, writes Mead: 
[...] passes into the universal meanings of common discourse and cooperative effort, and out of it arise the forms of universal beauty, the intuitions of the inventor, the hypothesis of the scientist and the creations of the artist. It is that part of the inner life of man which cannot be given its implicated meaning because of the incompleteness of social organization. (Mead 1964: 300, my italics)

In other words, in its most noble manifestations creativity functions as a complication of those very mechanisms that, when they act freely, produce dreams and empty daydreams, speaking the same language. Mead's recognition of the undeniable value of even those expressions of creativity springing from the unconscious mechanisms of thought is implicit in the possibility of future acquisition of the proposals of the " $I$ " on the part of society. The fact that at certain times society is not ready to accept them, Mead seems to suggest, does not diminish the communicative value of the productions of every individuality. ${ }^{10}$

The radically inter-subjective constitution of subjectivity enable Mead to certify the possibility of a sympathetic and emotional communication of meanings, whether totally or partially shared. In Whitman and in Emerson, and according to Mead as well, only the poet speaks the real authentic language, creating new meanings and, at the same time, protecting those still sharing in 'ordinary' life situations. After all, in 'The Poet' Emerson stated that in the poetic imagination is the 'place of birth' of language, ${ }^{11}$ according to a line of thought to which pragmatism has long been thought to be averse, however mistakenly:

[...] the poet is the Namer, or Language-Maker, naming things sometimes after their appearance, sometimes after their essence [...]. The poet made all the words, and therefore language is the archives of history, and, if we must say it, a sort of tomb of the Muses. For, though the origin of most of our words is forgotten, each word was at first a stroke of genius, and obtained currency, because for the moment it symbolized the world to the first speaker and to the hearer. (Emerson, 1844)

\section{Conclusion}

The relationship between the constructive moment of the individual personality and the reconstructive moment of the interpersonal relationship by means of which social transformations occur certainly deserves further attention. This problem, surely an important subject for discussion as regards the topic of the democratic ideal, should also be relevant in the light of the new concepts that philosophical anthropology proposes in its various anti-substantial forms. Criticism of an abstract rationalism now appears as a common denominator in these expressions. Awareness of the risk of assuming positions of an irrational or radically sceptical kind, bordering on nihilism, is likewise shared and shareable. I think that these latter positions invite us to return to the sources of pragmatism in its classical formulations. In that of George H. Mead, the interpretation of what I have tried to define as a form of imaginative rationality, leaving space for an idea of creativity founded upon the dynamics of the Self, still demands careful consideration. In Mead and in Dewey, the appeal to the ordinary and to everyday life ceases to identify itself with the established and/or the idiosyncratic and it becomes the reference to the dimension of commune and community. It is important to understand this dimension in all its complexity and richness precisely because of the radically inter-subjective constitution of subjectivity that subtends Mead's self-theory. In this perspective, normativity also does not arise - or impose itself - from the outside but is somehow 
constituent of every subjective intentional determination. Along these paths, pragmatic relativism objectifies itself, refusing to make absolute but erecting a steady barrier to skepticism and nihilism.

In the light of these observations, the question of the contribution that classical pragmatism can still offer may be presented on a broader basis and refer to some neglected issues that deserve revival. I am convinced that the value and effectiveness of these research hypotheses could be suitably tested both in the sociological and political fields; among these, the relation-ship between ethical and aesthetic experience - the loci of human action together with logic - assume a particular relevance, to connote the qualifying character of being human. This relationship has been overlooked in many respects, partly because of the overall homogeneity of historical interpretations of pragmatism, and partly owing to the controversial issues related to its descent from Transcendentalism. Questions connected to the variety of dimensions of human constitution find productive application in Mead's theory of perspectives and then run through Dewey's logic. Along this line, it is possible to discuss once more crucial ethical and political issues, such as that of "creative democracy." The pragmatist's researches, especially on the anthropological side, use a genetic and evolutionary approach to problems concerning the relationship between thought and action. This approach, especially in Mead, immediately escapes the narrow mesh of an environmental deterministic naturalism to reveal a phenomenological account of the complex and variegated processes of experience. Logic, aesthetics and ethics derive from those common human needs that constitute the grounds of genetic creativity, and it is not possible to create hierarchies of values between artistic productions, scientific skills or daily living discoveries (Mead 1934: 214). The problem of the relationship between imagination and intelligence and the other question, connected to it, but not overlapping, concerning the role of images in experience, find in Mead's proposals new, and productive, formulations. His anti-dualistic approach, loyal to the tradition of pragmatism, underlines all the richness and complexity of experiential human processes. Even if it is often abused, we could use the expression post-Darwinian to define Mead's rewriting of human evolution; an undertaking that, perhaps unexpectedly, leads him near to that place of the 'second birth' of humanity, as Vico suggests in his Scienza nuova: the starting point of a new human nature.

This 'nature' is not given but always needs to be rebuilt with a steady ethical commitment, if we believe that no part of humanity has the right to define itself as 'civilized' every time it ceases its struggle for create civilization.

\section{BIBLIOGRAPHY}

ALlen B., (1999), "Il Pragmatismo e le Gentili Muse europee," in Marchetti G. ed., Il Neopragmatismo, Firenze, La Nuova Italia, 1999, 28.

BERGSON H., (1889), Essai sur les données immédiates de la conscience, in Bergson H., CEuvres, ed. by H. Gouhier, Paris, PUF, 1970, 1-156. 
BERGSON H., (1907), L'évolution créatrice, in H. Bergson, CEuvres, ed. by Gouhier H., Paris, PUF, 1970, 487-812.

BLoom H., (1975), A Map of Misreading, New York, Oxford University Press.

COLAPIETRo V., (2009), “A Revised Portrait of Human Agency: A Critical Engagement with Hans Joas's Creative Appropriation of the Pragmatic Approach," European Journal of Pragmatism and American Philosophy, 1-2009, 1-24.

DARWIN C., (1859), On the Origin of the Species by means of Natural Selection, New York, Harper Collins Publishers, 2011.

DARWIN C., (1872), The Expression of Emotions in Man and Animals, Cambridge, Cambridge University Press, 2009.

EMERSON R. W., (1841-1844), Essays First and Second Series, New York, The Library of America, 2010. FERRARA A., (1998), Reflective Authenticity - Rethinking the Project of Modernity, London, Routledge. GoODMAN R. B., (1995), Pragmatism: A Contemporary Reader, London-New York, Routledge. HONNETH A., (1992), Kampf um Anerkennung. Zur moralischen Grammatik sozialer Konflikte, Frankfurt am Main, Suhrkamp. Italian translation, La lotta per il riconoscimento, Milano, Il Saggiatore, 2002. Honneth A., (1995), The Fragmented World of the Social. Essays in Social and Political Philosophy, Albany, State University of New York Press.

JAMES W., (1981), The Principles of Psychology, Cambridge, Harvard University Press [1890]. JOAS H., (1992), Die Kreativität des Handelns, Frankfurt am Main, Suhrkamp. English translation, (1996), The Creativity of Action, Oxford, Polity Press.

JOAS H., (1997), Die Entstehung der Werte, Frankfurt am Main, Suhrkamp. English translation, (2000), The Genesis of Values, Oxford, Polity Press.

JOYCE J., (1922), Ulysses, The Corrected Edition ed. by H. W. Gabler. Italian translation, (1991), Milano, Mondadori Editore,

MEAD G. H., (1932), The Philosophy of the Present (PP), ed. by A. E. Murphy, La Salle, The Open Court Publishing, 1959.

MEAD G. H., (1934), Mind, Self, and Society. From the Perspective of a Social Behaviorist, edited, with an Introduction, by Charles W. Morris, Chicago, University of Chicago Press.

MEAD G. H., (1964), Selected Writings, ed. by A. J. Reck, New York, The Bobbs-Merrill Co.

MEAD G. H., (1967), The Philosophy of the Act, Chicago-London, The University of Chicago Press.

MEAD G. H., (1982), The Individual and the Social Self. Unpublished Work of George H. Mead, edited, with an Introduction, by David L. Miller, Chicago-London, The University of Chicago Press.

NIEDDU A. M., (2001), “Creatività e valori in Hans Joas," La società degli individui, n. 12-anno IV, 159-163.

NIEDDU A. M., (2005), “G. H. Mead: Il sé ‘creativo’ e i processi di universalizzazione,” in R. M. Calcaterra (ed.), Semiotica e fenomenologia del sé, Torino, Aragno, 123-146.

NIEDDU A. M., (2011), "Individuality: The Emersonian Background of the Bergson-James Controversy," European Journal of Pragmatism and American Philosophy, I, 3-2011, 61-72. 
NUSSBAum M. C., (1995), Poetic Justice. The Literary Imagination and Public Life, Boston, The Beacon Press. Italian translation, Il giudizio del poeta. Immaginazione letteraria e vita civile, Milano, Feltrinelli, 1996.

nussbaum M. C., (2010), Not for Profit. Why Democracy Needs the Humanities, Princeton, Princeton University Press. Italian translation, Non per profitto. Perché le democrazie hanno bisogno della cultura umanistica, Bologna, Il Mulino, 2011.

PEIRCE C. S., (1903), 'The Three Normative Science' (Lecture V), in The Essential Peirce, ed. by The Peirce Edition Project, vol. 2, 196-207.

RIVERSO E. ed., (1982), Leggere Vico, Milano, Spirali.

STUHR J. J., (1997), Genealogical Pragmatism. Philosophy, Experience and Community, New York, State University of New York Press.

TUGENDHAT E., (1979), Selbstbewußtsein und Selbstbestimmung. Sprachanalytische Interpretationen, Suhrkamp Verlag, Berlin. Italian translation, Autocoscienza e autodeterminazione. Interpretazioni analitiche, Firenze, La Nuova Italia, 1997.

TAYLOR C., (1991), The Ethics of Authenticity, Cambridge/London, Harvard University Press.

VICo G., (1730), La scienza nuova 1730, ed. by P. Cristofolini \& M. Sanna, Napoli, Guida Editori, 2004.

WEST C., (1989), The American Evasion of Philosophy. A Genealogy of Pragmatism, Madison, The University of Wisconsin Press.

\section{NOTES}

1. The most relevant stages of this debate are Joas 1992; Joas 1997; Honneth 1992; Honneth 1995, and, in Italy, Ferrara 1998.

2. On this theme, see Honneth (1995: 261-72).

3. The stream of experiences that I am talking about refers evidently to William James' stream of consciousness, but in some way also implicates Bergson's durée réelle. I dealt with these themes in Nieddu 2005; Nieddu 2011.

4. I refer particularly to Chap. III of The Philosophy of the Present ('The Social Nature of the Present') and to one of the Supplementary Essays: 'The Objective Reality of Perspectives.'

5. I refer chiefly to the spontaneity of Bergson's "moi fondamentale" (Bergson 1889). Mead shares Bergson's idea relative to the temporalist substratum of subjectivity but he does not agree with its immediate expressivity.

6. In contemporary philosophical-political debate, Nussbaum $(1995 ; 2010)$ expresses the same demand. Nevertheless, she refers to the Transcendentalist tradition - in particular to Whitman 'bypassing' the most productive suggestions of pragmatism, like those derived from Mead's idea of human constitution.

7. I refer to part D ('The Stage of Consummation') of the 'General Analysis of Knowledge and the Act' (Mead 1967).

8. I refer, for example, to the studies that Max Harold Fish and Marcel Danesi dedicated to the Peirce-Vico relation.

9. In Joyce's most famous novel, the 'stream of consciousness' flows directly into narrative language. Mead read the chapters of Ulysses first published in The Little Review, a Chicago literary magazine.

10. This was also the destiny of Joyce's Ulysses. 
11. Vico had already expressed a similar conviction in his "sapienza poetica" (Vico 1730: 135ff.). On this point of contact between the Italian philosopher and Emerson, see Bloom 1975.

\section{ABSTRACTS}

A critical and aware return to pragmatism entails a preliminary focus upon the possibility of productive communication and a possible exchange among fields of research often far apart in terms of methods and spheres of application. This difficulty is felt all the more strongly if we refer to the contested intellectual legacy of George $\mathrm{H}$. Mead, one often divided between opposing and conflicting fields of investigation. In this paper, I propose a reinterpretation of his thought that I believe could operate transversally. To do so, I interpret Mead's idea of human creativity in a more radical way compared with some previous interpretations. This way, it is possible to see the constructive role of the relation between inter-subjective and intra-subjective communication as constitutive moments in an ethical self-construction of human beings. Finally, the peculiarity of human creativity, in all its complexity, shows itself as the starting point for responsible, normatively oriented conduct. Moreover, a new anthropological paradigm, also emerging from Mead's suggestions, could become a source of inspiration for a renewed pattern of civic life and democratic citizenship.

\section{AUTHOR}

\section{ANNA M. NIEDDU}

University of Cagliari

anieddu[at]unica.it 